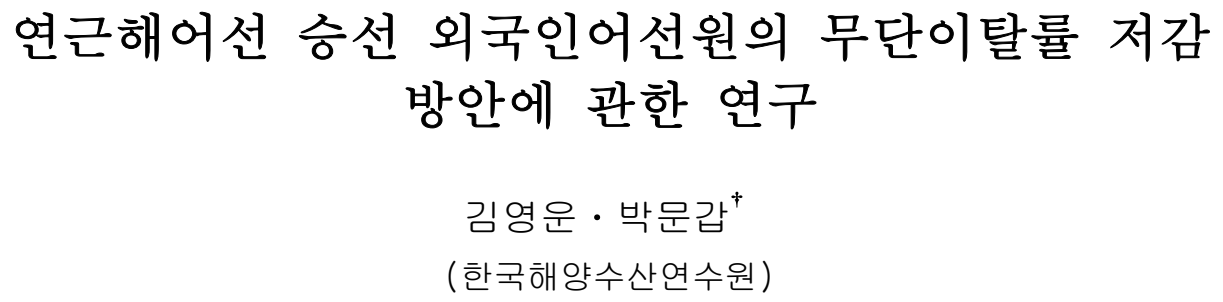

\title{
A Study on Devices of Reducing Foreign Fishermen's Rate of Deserting from Coastal and Offshore Fishing Vessels in Korea
}

\author{
Young-Un KIM $\cdot$ Moon-Kab PARK ${ }^{\dagger}$
}

(Korea Institute of Maritime and Fisheries Technology)

\begin{abstract}
The aim of this study is to reduce the foreign fishermen's rate of deserting from Korean coastal and offshore fishing vessel.

There are two employment systems for foreign fishermen who work on a coastal and offshore fishing vessel in Korea. One is employment permit system and the other is foreign seamen system. The former permits the foreign fishermen to work on the fishing vessels which are less than 20 gross tonnage. The latter permits the foreign fishermen to work on the fishing vessels which are more than 20 gross tonnage.

The recent rate of deserting from their workplace are $21.5 \%$ in foreign seaman system and $26.8 \%$ in employment permit system by October 2011.

In this paper, the authors propose eight means to reduce the rate of deserting from their workplace.

Key words : Employment permit system, Foreign seamen system, The rate of deserting from their workplace.

\section{I. 서 론}

근래 우리나라 도시나 어촌의 항구에서 연근해 어업에 종사하고 있는 외국인어선원들을 많이 접할 수 있다. 우리나라에서 어선원이라는 직업을 $\left.3 \mathrm{D}^{1}\right)$ 업 종의 하나로 인식하고 있어서 취업을 기피하고 있

1) $3 D$ 는 Dangerous, Dirty, Difficult를 뜻함.

고 또한 상대적으로 다른 직종에 비하여 임금마저 낮아 구인난이 심각하다. 따라서 이러한 외국인 어 선원은 이미 우리 수산업에서 빠질 수 없는 노동력 으로 자리하고 있다.

이러한 외국인어선원의 고용에는 현행 두 가지 국내법 제도에 의하여 이루어지고 있다. 먼저 20 톤 미만 연근해어선에 고용되어 일하는 고용노동부 의 고용허가제이다. 다음은 20 톤 이상의 연근해어
\end{abstract}

† Corresponding author: 051-620-5809, mkpark1953@hanmail.net 
선에 승선하여 일하는 국토해양부의 외국인선원 제가 있다.

그러나 고용허가제와 외국인선원제 모두에서 연근해어업에 취업하고 있는 외국인어선원의 무 단이탈률이 매우 높다. 이로 인하여 적시에 출어 시기를 놓쳐 어업 경영에 많은 손실을 끼치고 있 으며 부족한 선원으로 조업할 수밖에 없어 나머 지 선원에게 있어서는 가혹한 노동환경에 더욱 노동 강도를 높여 국내 선원들이 어업 현장에 나 서길 꺼려하는 등 어려운 어업경영에 어려움을 가중시키고 있다.

한편, 무단이탈한 외국인어선원은 대부분 육상 으로의 불법체류로 이어져 인권문제, 폭력발생 등 각종 사회문제가 되고 있다.

이에 본 연구에서는 외국인어선원의 무단이탈 률을 조사하여 무단이탈의 가장 큰 원인으로 지 목하는 외국인어선원의 임금을 분석하고 외국인 어선원 고용에 관한 두 가지 제도의 운용을 관찰 함으로서 외국인어선원의 무단이탈률 저감에 대 한 방안을 제시하고자 한다.

\section{II. 자료 및 방법}

연구는 통계 등 자료를 통한 문헌연구와 면접 및 설문조사 방법을 사용하였다. 문헌연구에 사 용한 통계 등은 정부기관으로는 국토해양부와 농 림수산식품부, 사용자 단체로는 수협중앙회를 비 롯한 지구별과 업종별 수협, 선원관련단체로는 어선원 노동조합과 외국인선원 송출업체 및 외 국인선원 관리업체의 자료를 사용하였다.

면접 및 설문조사는 지구별과 업종별 수협, 연 근해어선 소유자, 외국인어선원 관리업체 관계자, 한국인선원 및 외국인어선원을 대상으로 실시하 였다. 연구 범위는 우리나라 연근해어선에 승선 하여 일하는 외국인어선원으로 한정하였으며 정 박 중이거나 하역작업 중인 어선을 탐방하여 외 국인어선원의 모국어로 작성한 설문조사와 면접
을 동시 실시하였다.

\section{III. 연구 결과}

\section{1. 연근해어업에 종사하는 외국인어선원의 고용 제도 변천}

가. 산업연수생제도

우리나라는 $3 \mathrm{D}$ 업종에서 인력난 및 외국인 불 법 취업 증가로 1991년 11월 해외투자업체 연수 제도를 도입하였고, 1993년 12월에는 「외국인 산업기술연수제도」를 도입하였다. 연근해어선에 서는 1996년 처음으로 외국인어선원으로 부원 1 천명을 시범적으로 도입하였다.

그러나 $3 \mathrm{D}$ 업종 인력난의 심화됨에도 불구하고 외국인의 공급은 산업연수생제도라는 명분 때문 에 매우 제한적으로 이루어졌다. 그리고 산업연 수생제도는 외국 인력을 사실상 노무에 종사하게 하면서 근로자 신분이 아닌 연수생 신분으로 활 용함으로써 외국 인력의 편법 활용, 사업장 이탈, 체불임금, 외국인 근로자의 인권침해 등의 많은 사회문제를 야기하였다.

이런 산업연수생제도의 한계 때문에 합법적인 외국인력 공급이 제대로 이루어지지 않아 불법체 류 외국인을 양산하는 주요인으로 작용한다는 비 판이 지속적으로 제기되었다. 2002년 12월 국내 체류 외국인력 약 363,000 명 중 불법체류자는 약 290,000 명으로 전체 체류 외국인의 $80 \%$ 에 달하여 인권침해를 비롯한 각종 사회문제와 주택, 의료 등 사회적 고비용이 발생하는 등 외국인에 대한 효율적인 관리체계가 요구되었다.

나. 고용허가제

산업연수생제도의 문제점을 근본적으로 해결하 기 위하여 정부는 1990 년대 중반부터 외국인 고 용허가제의 도입을 수차례 시도하였으나 경영계 의 반대로 그 뜻을 이루지 못하였고, 고용허가제 의 도입이 지연되자 2000년 4월부터 연수취업제 를 시행하여 산업연수생이 일정기간 연수생으로 
근무한 후 근로자 신분으로 전환하여 취업할 수 있도록 허용하였다. 이후 계속되는 생산직 인력 난을 완화하고 외국인 고용관리체계의 기틀을 확 립하기 위하여 2003년 8월 16일 「외국인근로자의 고용 등에 관한 법률」을 제정하여 고용허가제를 도입하였다.

외국적 동포에게 방문 동거 체류 자격을 부여 하고 국내에서 취업 활동을 하도록 한 취업관리 제는 고용허가제에 흡수 통합되었으며, 기존의 산업연수생제도는 2006년까지는 고용허가제와 병 행하여 시행하고 2007년 1월 1일부터는 산업연수 생제도를 폐지하고 고용허가제로 통합하였다.

한편, 수산분야에서는 고용허가제 하에서 총톤 수 20 톤 미만의 연근해어선과 양식업의 근로자는 비숙련 노동자로 분류하여 체류 자격(E-9)을 부여 하여 외국인어선원을 고용하고 있다.

다. 외국인선원제

종전의 산업연수생제도에서는 총톤수 10 톤 이 상의 연근해어선에 외국인어선원을 고용하였으나 고용허가제로 외국인 근로자 고용제도가 변경되 면서 근로기준법의 적용을 받지 않고 선원법 적용 을 받는 총톤수 20 톤 이상의 연근해어선에 승선하 여 일하는 외국인어선원은 체류자격으로서 E-10-B 를 부여하여 별도 운용하고 있다. 즉, 연근해어업 에서의 외국인어선원 고용은 현재 고용허가제와 외국인선원제로 이원화되어 운영되고 있다.

\section{2. 고용 절차와 규모}

가. 고용허가제에 따른 고용

고용허가제는 국내 인력을 구하지 못한 사업자 에게 외국인 근로자를 합법적으로 고용할 수 있 도록 정부가 허가해 주는 제도로서 국무총리실 산하에 외국인력정책위원회를 설치하여 매년 국 내 인력수급 동향과 연계하여 외국인 근로자 관 련 기본계획을 수립하고 도입 규모 및 업종과 송 출 국가를 선정하고 있다.

외국인어선원 송출 국가는 우리 정부와 양해각
서(MOU)2)를 체결한 필리핀, 태국, 인도네시아 등 15 개 국가이며 주무부처는 고용노동부이다.

외국인 근로자 도입 절차는 다음과 같다. 1) 내국인 구인 노력, 2)외국인 고용 허가 신청, 3) 고용허가서 발급, 4) 근로계약 체결, 5) 사증발급 인정서 발급, 6) 외국인 근로자 입국 및 취업교 육, 7) 사업장 배치, 사업장 고용 및 체류지원 순 서로 이루어진다.

고용허가제에 의한 외국인어선원 적용 대상은 근로기준법 적용을 받는 총톤수 20 톤 미만의 연 근해어선에 취업하고자 하는 외국인 근로자이며 고용 규모는 승선 어선원의 $40 \%$ 이내로서 척당 2 명 이내로 제한하고 있다.

나. 외국인선원제에 따른 고용

외국인선원제는 국토해양부 고시 「외국인선원 관리지침」제 2 장 제 3 조(업종별 고용기준 결정)에 따라 어선원 인력난을 겪고 있는 총톤수 20 톤 이 상의 연근해어선에 외국인어선원을 고용하고자 하는 제도이다.

외국인어선원 송출국가는 중국, 인도네시아, 베 트남의 3개국이며 주무부처는 국토해양부이다.

외국인어선원 도입절차는 수협중앙회의 추천, 송입을 통해 다음과 같이 이루어진다.

1) 외국인 고용 신청, 2) 외국인어선원 고용 관 련 노측 의견서 첨부, 3) 외국인어선원 고용추천 서 발급 신청 및 발급, 4) 외국인어선원 고용신고 및 고용신고 수리서 발급, 5) 외국인어선원 사증 발급 신청, 6) 외국인어선원 입국, 7) 사업장 배 치, 사업장 고용 및 사후관리 순서로 이루어진다. 외국인선원제에 의한 외국인어선원 적용 대상 은 선원법 적용을 받는 총톤수 20 톤 이상의 연근 해어선이다.

연근해어선에서의 외국인어선원 고용기준은 해 상노동조합과 수산업협동조합중앙회가 자율적으 로 합의하여 정하도록 하고 있다. 선원법이 적용 되는 20 톤 이상 연근해어선은 고용허가제와 달리

2) MOU는 양해각서(Memorandum Of Understanding)를 뜻함. 
외국인선원제도로 별도 운용되어 고용대상 선박 은 대형기선저인망어업, 중형기선저인망어업, 근 해트롤어업, 근해채낚기어업, 근해자망어업, 근해 안강망어업, 근해통발어업, 근해연승어업, 기선선 인망어업, 근해선망어업, 근해봉수망어업, 정치망 어업 등 총 12 개의 어업이다.

그리고 혼승 대상 외국인 어선원은 부원에 한 하며, 혼승 인원은 척당 5명 이내로 하되 전체 어선원의 $50 \%$ 를 초과하지 못하게 되어 있다.

다. 고용허가제와 외국인선원제의 고용 차이 고용허가제는 우리나라 정부와 15 개국 정부와 의 사이에 $\mathrm{MOU}$ 를 체결하여 송출기관, 도입기관 이 모두 정부기관인데 비하여 외국인선원제는 국 내 민간업체인 송입업체(관리업체)에서 위탁받아 송출기관인 송출국의 민간업체(국가 주도로 운용 하는 업체도 있음)에서 외국인어선원을 전원 선 발하여 우리나라의 관리업체에 인도하는 방식이다.

\section{3. 외국인어선원 무단이탈 현황}

\section{가. 외국인선원제}

<표 1>은 2007년도 외국인선원제에 따라 연근 해어업에서 외국인선원제가 시행된 이후부터 연 근해어업에서 연도별, 국가별 외국인어선원 입국 자 및 무단이탈자 현황이다. 외국인어선원 입국 자 현황을 국적별로 보면 2011년 10월까지 총 11,402 명 중 중국 국적은 약 $61 \%$ 인 6,927 명, 인도 네시아 국적은 약 $24 \%$ 인 2,699명, 베트남 국적은 약 $15 \%$ 인 1,776 명이 입국하였다.

통계상으로는 현재까지는 중국 국적이 가장 많 으나 선주 및 조합 관계자의 설문 및 면담에 따 르면 중국의 높은 경제성장률과 함께 중국내에서 의 임금도 점차 증가하고 있으므로 양질의 선원 공급이 어렵다.

따라서 선원 송출 3 개국 중 많은 선사에서 중 국보다는 베트남 또는 인도네시아 선원을 희망하 고 있어 향후 중국 선원의 감소율은 높아질 것으 로 예상된다.

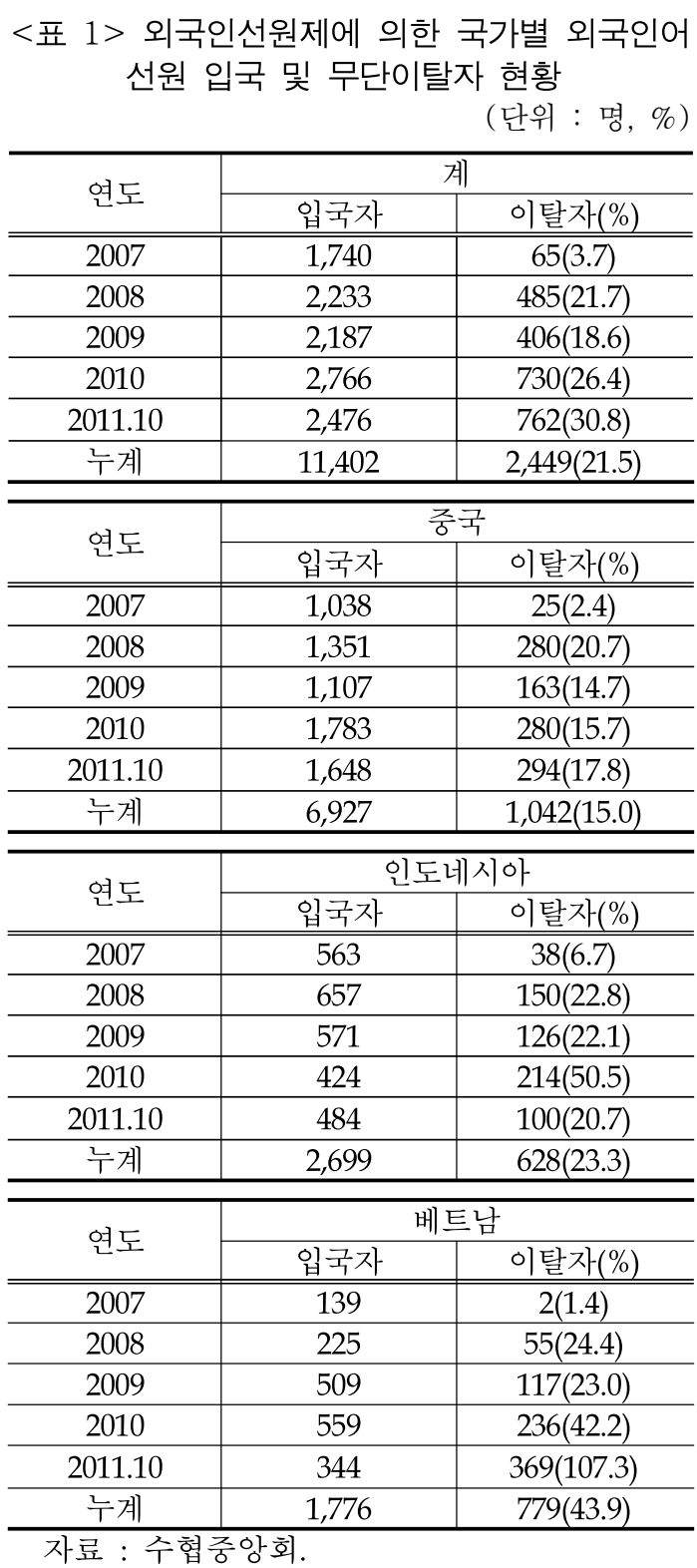

한편, 우리 사회에 문제가 되고 있는 무단이탈 률은 중국 $15 \%$, 인도네시아 $23 \%$, 베트남 $44 \%$ 이 고, 이들 3 개국의 평균이탈률은 $21.5 \%$ 이다. 특히, 베트남 국적자의 무단이탈률이 높게 나타난 것은 베트남 어선원들의 친인척, 친구 등이 국내에 많 이 거주하고 있어서 입국한 선원들이 이러한 사 람들과 정보교환이 쉽게 이루어지는 것도 한 원 
인이다. 고용허가제도의 경우를 보더라도 대한민 국 고용노동부가 $\mathrm{MOU}$ 체결을 맺고 있는 15 개 국가 중 베트남 근로자의 이탈률이 타 국가에 비 하여 현저히 높아 ' 11 년도에는 고용노동부에서 현지 한국어시험 실시를 보류하여 근로자 도입을 차단하기도 하였다. 보다 근본적인 문제는 근로 환경이 열악한 어선보다는 비교적 근로환경도 좋 고 임금도 많은 육상의 산업체로의 이동 때문이 다.

나. 고용허가제

<표 2>는 2007년부터 고용허가제에 따라 연근 해 어업분야에 들어온 연도별 입국자 현황을 나 타내고 있다. 2007년 422명을 시작으로 2011년에 는 1,809 명으로 약 4.3 배 늘어났다.

<표 2> 고용허가제에 의한 외국인어선원의 입국 현황

(단위 : 명)

\begin{tabular}{c|c|c|c|c|c|c}
\hline 연도 & 2007 & 2008 & 2009 & 2010 & 2011.10 & 계 \\
\hline \hline 입국자 & 422 & 1,241 & 1,026 & 963 & 1,809 & 5,461 \\
\hline 자료 : 수협중앙회.
\end{tabular}

<표 3>은 고용허가제로 입국한 외국인어선원 과 비전문 취업자(전체)의 불법체류율을 나타낸 표이다. 외국인선원으로 입국한 5,056명은 전체 비전문취업자수 239,179 명의 $2.1 \%$ 를 차지하고 있 으며 외국인어선원의 불법체류율이 비전문취업자 (전체)에 비해 $9 \%$ 높게 나타난 것은 노동강도가 높은 어로현장보다는 제조업 등에서의 불법근로 가 훨씬 편하고, 더 많은 돈을 벌 수 있기 때문 에 육상으로 이동했기 때문으로 생각된다.

<표 3> 고용허가제의 불법체류율(2011년)

(단위 : 명)

\begin{tabular}{c|c|c|c|c}
\hline $\begin{array}{c}\text { 구분 } \\
(\mathrm{E}-9)\end{array}$ & $\begin{array}{c}\text { 총 } \\
\text { 체류자 }\end{array}$ & $\begin{array}{c}\text { 합법 } \\
\text { 체류자 }\end{array}$ & $\begin{array}{c}\text { 불법 } \\
\text { 체류자 }\end{array}$ & $\begin{array}{c}\text { 불법 } \\
\text { 체류율(\%) }\end{array}$ \\
\hline \hline 외국인선원 & 5,056 & 3,702 & 1,354 & 26.8 \\
\hline $\begin{array}{c}\text { 비전문취업 } \\
\text { 자(전체) }\end{array}$ & 239,179 & 196,660 & 42,519 & 17.8 \\
\hline \multicolumn{3}{|c|}{ 자료 : 법무부 통계월보. }
\end{tabular}

다. 외국인어선원의 무단이탈 현황 비교 고용허가제와 외국인선원제로 입국한 외국인 어선원이 무단이탈하여 불법으로 체류하는 비율 을 보면 외국인선원제도로 입국한 선원의 무단이 탈률은 $21.5 \%$, 고용허가제로 입국한 외국인선원 의 불법체류율은 $26.8 \%$ 로 나타나 고용허가제로 입국한 외국인어선원의 무단이탈률이 $5.3 \%$ 높다.

고용허가제에 의한 무단이탈률이 외국인선원제 에 비해 높게 나타나는 이유는 고용허가제는 한 국어능력시험에 합격한 자에 한하여 선발되며 승 선 유무, 신체조건 등이 전혀 고려되지 못한 데 반하여 외국인선원제는 무단이탈률이 과도한 송 출업체에게는 자격취소 등 행정상 벌칙이 따르므 로 모집하는 과정에서 신체조건, 승선 유무 등 어업 현장에 적응할 수 있는 선원들을 선별한다 는 점이 그 원인의 하나로 생각된다.

한편, 이러한 무단이탈의 이면에는 개인의 과 다 송출비용을 단기간에 만회하기 위해서 임금이 높은 육상의 제조업으로 불법 브로커들이 조직적 으로 이들을 유인해서 알선해 주고 있고 무엇보 다도 불법 근로에 대한 단속과 처벌이 심하지 않 다는 점이 그 원인으로 조사되었다.

\section{4. 임금}

\section{가. 최저임금}

임금은 선원근로관계에 가장 중요한 근로조건 으로서 선원의 이탈에 가장 큰 영향을 미친다.

국내의 어선원에 적용되는 임금의 경우, 임금 지급 형태로는 고정급제, 짓가림제, 고정급병용짓 가림제 등 여러 가지가 있고 임금지급 결정방법 도 단체 협약과 개별 협약으로 분류된다.

국내선원의 최저 임금은 선원법 제54조(최저임 금) 및 국토해양부 고시(선원최저임금 고시)에 규 정되어 있으며 선원최저임금은 국내 선원의 생존 권 보호와 사용자의 경영상황을 고려하여 노·사 간 자율적 합의로 결정된 것으로 최저임금액에 미달하는 임금을 정한 선원근로계약은 무효이며, 
단체협약의 월고정급이 월 최저임금액에 미달하 는 경우에는 고시된 최저임금액으로 지급해야 한 다.

총톤수 20 톤 이상의 선박에 승선하는 외국인선 원의 최저임금은 특례 조항에 의해 해당 노·사간 단체협약으로 최저임금을 정할 수 있게 되어 있 다. 따라서 사용자 대표인 수협중앙회와 노동자 대표인 해상노동조합간에 단체협약으로 결정된 다. 최저임금은 직책이나 통상임금 및 평균임금 과 관계없이 일괄적으로 최저액만을 정한다. 그 러나 총톤수 20 톤 미만의 연근해어선에 승선하는 외국인어선원은 고용허가제에 의하여 고용되므로 단체협약 없이 육상의 최저임금이 적용된다.

단, 1 년 이상 승선 근무하는 경우에는 업종별 로 근속 수당이 지급되며 업종별로 약간의 차이 가 있으며 같은 업종에서도 어선소유자 또는 어 획고에 따라 차이가 있고 그 외에도 별도의 생산 독려 수당이 지급되기도 한다.

<표 4>는 연근해어선에서 근로하는 국내 어선 원과 고용허가제로 고용된 외국인어선원 및 외국 인선원제에 의해 고용된 외국인어선원의 임금을 비교하여 나타내고 있다.

2011년도 최저임금을 국내 선원최저임금은 월 $1,163,000$ 원에 비해 고용허가제의 외국인어선원은 월 976,320원, 외국인선원제의 외국인어선원은 월 900,000 원이다. 외국인선원제의 900,000 원은 한국 인선원 최저임금의 $77 \%$ 수준이며 고용허가제 임 금의 $92 \%$ 수준이다.

최근 5 년간 외국인선원제의 임금 상승액이 가 장 적으며 특히 외국인선원제로 고용된 어선원은 고용허가제로 고용된 어선원에 비해 $8 \%$ 정도 낮 아 임금차이를 크게 느낄 수도 있다.

더욱이 먼 바다에 나가 근무해야 하는 외국인 선원제도에 의하여 고용된 어선원의 경우, 근무 강도는 더 세고 환경은 더 열악한 상황에서 고용 허가제로 고용된 어선원의 임금 또는 육상의 근 로자보다 낮은 임금은 외국인어선원의 사업장 이 탈을 가속화시키는 주요인으로써 작용하고 있으
<표 4> 연근해어선원 연도별 고용제도별 최저 임금 변화 현황 (단위 : 원)

\begin{tabular}{|c|c|c|c|}
\hline $\begin{array}{l}\text { 고용 } \\
\text { 제도 }\end{array}$ & $\begin{array}{l}\text { 국내선원 } \\
\text { 최저임금 }\end{array}$ & $\begin{array}{c}\text { 고용 } \\
\text { 허가제 } \\
\text { (20톤미만) }\end{array}$ & $\begin{array}{c}\text { 외국인 } \\
\text { 선원제 } \\
\text { (20톤이상) }\end{array}$ \\
\hline 2007 & 906,000 & 786,480 & \multirow{2}{*}{750,000} \\
\hline 2008 & 983,000 & 852,020 & \\
\hline 2009 & $1,060,000$ & 904,000 & \multirow{2}{*}{800,000} \\
\hline 2010 & $1,098,000$ & 928,860 & \\
\hline 2011 & $1,163,000$ & 976,320 & 900,000 \\
\hline $\begin{array}{l}\text { 5년간 } \\
\text { 상승액 }\end{array}$ & 257,000 & 189,840 & 150,000 \\
\hline $\begin{array}{c}\text { 5년간 } \\
\text { 인상율 }(\%)\end{array}$ & 28.4 & 24.1 & 20.0 \\
\hline
\end{tabular}

며 총톤수 20톤 미만과 총톤수 20톤 이상 어선을 한 어선 소유자가 같이 소유하는 경우에도 외국 인어선원은 어느 어선을 승선하느냐에 따라 임금 의 차이가 발생하기도 하는데 동일 근로 조건에 서 법적용 제도로 인해 각기 다른 임금을 받는 것은 형평성에도 문제가 있다. 그러므로 상대적 저임금에 따른 외국인선원제로 고용된 어선원의 무단이탈을 방지하기 위해서도 고용허가제와 같 은 최저임금을 적용할 필요가 있다.

나. 외국인선원제 어선원의 임금 고찰

연근해어선에 종사하는 외국인선원제에 의해 고 용된 외국인어선원은 어업형태와 관계없이 2011 년 5월 1 일 체결된 노사합의에 따라 일률적으로 생산수당, 시간외 수당, 야간 및 휴일 근무 수당 등 제 수당이 포함된 최저임금으로 월 900,000원 이 되었다.

또한 조합별 또는 어선 소유자에 따라서 개별 적으로 작업 독려 차원에서 일정액의 수당을 지 급하거나 보합제를 적용하는 업종에서는 선원들 의 보합비율에서 일부분을 떼어 지급하기도 하나 외국인어선원에게의 보합은 원칙적으로 적용하지 않고 있다.

<표 5>는 임금에 대하여 단위조합을 방문하여 설문조사한 자료이며, 설문 응답 조합의 1 년차 
근무의 경우 월평균 급여는 928,000 원으로 노사 합의에 의한 최저임금보다 높게 나타났으며 이는 무단이탈 방지 및 별도의 생산독려 수당이 포함 된 것으로서 외국인어선원을 장기 고용하려는 노 력의 일환으로 볼 수 있다.

그리고 대부분의 조합에서 외국인어선원의 장 기근속을 유도하기 위하여 최저임금에 연차별로 임금을 올려 지급하고 있다.

<표 5> 조합별 외국인어선원 월 임금 현황

(단위 : 천원)

\begin{tabular}{|c|c|c|c|c|}
\hline \multicolumn{2}{|c|}{ 조합별 연차 } & 1년차 & 2년차 & 3년차 \\
\hline \multicolumn{2}{|c|}{ 대형선망 } & 900 & 950 & 1,000 \\
\hline \multicolumn{2}{|c|}{ 서남구저인망 } & 900 & 950 & 1,000 \\
\hline \multicolumn{2}{|c|}{ 기선권현망 } & 900 & 950 & 1,000 \\
\hline \multicolumn{2}{|c|}{ 전남정치망 } & 1,000 & 1,200 & 1,300 \\
\hline \multirow{4}{*}{$\begin{array}{c}\text { 근해 } \\
\text { 안강망 }\end{array}$} & 여수 & 900 & 1,000 & 1,200 \\
\hline & 인천 & 1,000 & 1,100 & 1,300 \\
\hline & 군산 & 900 & 1,100 & 1,300 \\
\hline & 목포 & 950 & 1,050 & 1,150 \\
\hline \multicolumn{2}{|c|}{ 평 균 } & 928 & 1,026 & 1,137 \\
\hline
\end{tabular}

자료 : 업종별 조합 설문조사.

<표 6>은 어업별 선원 1 인당 평균임금을 나타 내고 있다. 이 표에서는 선원의 종사수는 외국인 어선원도 포함되어 있고 월 평균임금은 어업 종 사기간(월)으로 나눈 금액이다. 따라서 연중 12 월 로 산정한 임금보다 평균임금이 높게 나타나며 <표 5>의 외국인어선원 3년차의 임금과 단순 비 교하면 전체적으로 외국인선원의 임금은 선원 1 인당 평균 임금의 약 $31 \%$ 에 불과하다.

\section{5. 외국인어선원 제도 비교}

\section{가. 외국인선원제의 장·단점}

장점으로는 수협중앙회와 해상노동단체와의 외 국인어선원의 도입 인원 합의시, 총톤수 20 톤 이 상 연근해어선의 부족 인력을 중점으로 하여 도 입 인원이 결정된다.

따라서 업종별 부족인력 이외에 국내 노동시장
<표 6> 어업별 선원 1인당 평균임금(2010년)

(단위 : 천원)

\begin{tabular}{|c|c|c|c|c|}
\hline 업 종 & $\begin{array}{l}\text { 종사자 } \\
\text { 수(명) }\end{array}$ & $\begin{array}{c}1 \text { 인당 연 } \\
\text { 평균임금(A) }\end{array}$ & $\begin{array}{l}\text { 조업기간 } \\
\text { 월) (B) }\end{array}$ & $\begin{array}{l}\text { 월평균임 } \\
\text { 금(A/B) }\end{array}$ \\
\hline 정치망어업 & 12 & 1010,375 & 9 & 1.153 \\
\hline $\begin{array}{l}\text { 쌍끌이대형 } \\
\text { 저인망어업 }\end{array}$ & 8 & 39,109 & 11 & 3,555 \\
\hline $\begin{array}{l}\text { 외글이대형 } \\
\text { 저인망어업 }\end{array}$ & 14 & 34,366 & 11 & 3,124 \\
\hline 대형트롤어업 & 9 & 70,718 & 10 & 7,011 \\
\hline $\begin{array}{c}\text { 동해구 } \\
\text { 외끌이중형 } \\
\text { 저인망어업 }\end{array}$ & 9 & 14,197 & 11 & 1,291 \\
\hline $\begin{array}{c}\text { 서남해구 } \\
\text { 외끌이중형 } \\
\text { 저인망어업 }\end{array}$ & 8 & 48,175 & 11 & 4,380 \\
\hline $\begin{array}{c}\text { 동해구중형 } \\
\text { 트롤어업 }\end{array}$ & 10 & 84,431 & 7 & 12,062 \\
\hline 대형선망어업 & 73 & 46,249 & 11 & 4,204 \\
\hline $\begin{array}{c}\text { 기선권현망 } \\
\text { 어업 }\end{array}$ & 45 & 21,396 & 9 & 2,377 \\
\hline 근해통발어업 & 10 & 27,823 & 9 & 3,091 \\
\hline $\begin{array}{c}\text { 근해안강망 } \\
\text { 어업 }\end{array}$ & 8 & 26,670 & 10 & 2,667 \\
\hline $\begin{array}{c}\text { 근해채낚기 } \\
\text { 어업 }\end{array}$ & 8 & 22,174 & 7 & 3,168 \\
\hline 근해자망어업 & 10 & 25,736 & 7 & 3,677 \\
\hline 근해연승어업 & 9 & 31,718 & 9 & 3,524 \\
\hline 평 균 & 10 & 29,696 & 8 & 3,611 \\
\hline
\end{tabular}

자료 : 2011년 어업경영조사보고, 수협.

의 인력수급 현황 및 내국인 고용기회 보호 등 각종 제반사항을 고려하여 도입규모가 결정되는 고용허가제에 비해, 부족한 인력규모 반영이 보 다 용이하고 어업분야 외국인력 공급과 관련한 각종 사항에 신속히 대처할 수 있다.

또한 외국인선원시스템 개발 등 업무 전산화로 도입기간이 약 40 일 정도로 대폭 단축되었고, 수 협중앙회 및 회원조합을 통하여 단일 창구 신청 등 각종 행정 편의를 도모하고 있으며, 민간 사 후 관리업체를 통해 사고 수습 등 출국에서부터 이탈까지 각종 사후관리가 수월하여 인력난에 처 한 연근해어선에 적기에 인력을 공급할 수 있다. 단점으로는 고용허가제는 도입 규모, 업종, 도 
입국가 등 외국 인력정책의 주요 사항이 국무총 리실 산하의 외국인력정책위원회에서 결정되고 인력수급동향 등을 토대로 위원회의 심의를 거쳐 업종별 도입규모가 결정되는데 반해, 외국인선원 제의 경우, 수협중앙회와 해상노동단체와의 매년 합의에 의해 도입 규모를 포함한 근로기준이 결 정됨으로서 해상노동단체와의 합의가 잘 이뤄지 지 않을 때는 총톤수 20 톤 이상의 연근해어선에 서 외국인선원의 도입 지연 사태 발생이 우려된 다.

주무부처인 국토해양부는 선원정책 담당부서로 서, 어선소유자의 권익에 부합하는 종합적, 전문 적 인력 정책을 수립하기에는 한계가 있으며 해 상노동단체와 수협중앙회 및 주무부처 등 유관기 관의 입장이 서로 상이할 때 중재기관이 필요하 다. 또 개인의 송출비용이 과다하고 어선소유자 에게는 외국인선원에 대한 선원관리비 및 관리수 수료 등 급여 이외에 부담 비용이 과다하다는 주 장이 있다.

나. 고용허가제의 장.단점

장점으로는 외국인근로자의 도입.관리를 고용 노동부에서 관장하여 인력도입의 투명성, 공정성 에 크게 기여하고 있으며 외국인선원에게 있어 적은 송출비용으로서 한국의 노동 시장에 진출하 고 있다.

단점으로는 고용허가제는 사후관리를 고용센터 및 한국산업인력공단이 담당하고 있다. 그러나 어선원의 고용이 필요한 어선들은 대부분 연안 도서에 위치하고 있다. 따라서 주로 대도시에 소 재하는 고용센터 및 한국산업인력공단의 사업장 과 같이 접근하기 어렵고 어업 현실에 대한 이해 부족으로 사후관리가 미흡하여 어업분야 소외 현 상이 야기되고 있다.

어업은 고용허가제 전체 업종 중 2011년 도입 인원은 규모 기준 $3.6 \%$ 를 차지하는데 불과하고, 어업의 특수성, 어려움을 반영하여 어업분야에 적합한 인력선발 및 공급 정책 수립 등이 현재로
서는 미비한 실정이다.

어업의 무단이탈률이 다른 업종에 비해 월등히 높음에도 사후관리시스템의 약화로 입국 후 무단 이탈, 근로계약해지, 각종 상해 발생 때 처리가 불편하고, 근로자와 어선 소유자 사이의 언어 소 통문제, 애로사항 등의 해결이 원활하지 않아 안 정적인 근로환경 조성에 애로가 많다.

연근해어업의 특수성 반영에 한계가 있으며 어 업 기피 현상이 심각하고 개인의 승선경력 불인 정 등에 따른 상대적 저임금 등으로 다른 업종과 비교하게 되는 등 외국인근로자의 취업 기피 현 상은 보다 심각하고 입국하여 수일 내에 무단이 탈 또는 사업장 변경을 위한 근로계약 해지 요구 가 빈발하고 있는 실정이다.

노동 강도가 가장 혹독한 근로환경에서도 최저 임금제가 동일하게 적용되어 어업 현장에서의 경 험도나 숙련도와 관계없이 최저임금 이외에 약간 의 생산독려수당을 포함, 통상 100 만원미만의 수 준의 낮은 임금을 받고 시작하고 있으나 어선 소 유자의 입장에서는 반대로 숙식비 제공 및 그 외 에도 4 대 보험 가입, 퇴직금 지급의무 등 내국인 과 동등한 대우를 하기 위해 소요되는 추가적인 비용이 영세어가에는 큰 부담으로 작용한다. 실 질적으로 외국인 선원의 1 년차 1 인당 고용 실비 용은 월 150 만원 이상이 소요된다.

고용센터, 대행기관 및 출입국 관리사무소 등 행정 처리를 하여야 하는 기관이 분산되어 있어 행정처리가 복잡하고 처리기간이 길어진다. 따라 서 적기에 필요한 외국인어선원이 충원되지 못하 여 어기에 출어하지 못하는 경우도 빈번하게 발 생하고 있다.

\section{IV. 결론 및 제언}

연근해어업 현장에서 외국인선원 관리에서 가 장 큰 문제로 대두되고 있는 무단이탈률을 저감 할 수 있는 방안을 다음과 같이 제안한다. 
첫째 외국인어선원의 무단이탈은 다른 사업장 의 상대적으로 높은 임금과 송출 비용의 과다 지 출이 주요인이므로 임금을 높이는 한 방법으로 외국인선원제에 의해 고용된 어선원 임금은 고용 허가제로 고용된 어선원 임금과 적어도 동일하게 하거나 차츰 증가시켜야 한다. 그리고 개인의 송 출비용의 절감을 위해서 「외국인근로자의 고용 등에 관한 법률」 중 외국인선원의 고용에 적합한 제도를 준용하는 규정을 도입하여야 한다고 본 다.

둘째 무단이탈률이 높은 외국인어선원 출신 국 가의 도입 규모는 줄이고 대신 도입 국가를 확대 해 나가는 방식을 도입하여야 한다.

세째 무단이탈률이 높은 외국인어선원 관리업 체에 대해서는 행정벌의 형량을 높여 외국인어선 원의 사후관리에 더욱 노력케 할 필요가 있다.

네째 무단이탈률이 높은 국가의 어선원 송출 담당 정부부서에서 무단이탈 후 귀국하면 여러 가지 행정 및 형사처벌을 하는 제도를 구축하도 록 권장한다. 이를 위하여 정부간에 협의역량을 강화하고, 그 실행여부를 점검하는 것이 중요하 다.

다섯째 언어 소통의 어려움에서 발생하는 갈등 과 불화를 감소시키고 사회문화적 배경차이에서 발생되는 사고와 인식의 차이를 극복하기 위해서 외국인어선원 입국 교육 때 한국어능력평가시험 을 통하여 한글을 전혀 읽지 못하는 자, 소통이 전혀 불가능한 자는 부적격자로 판정하여 한국어 구사 능력을 일정 수준으로 올려야 한다.

여섯째 외국인선원제 및 고용허가제의 장점을
살리고 어업의 특수성을 반영할 수 있는 통합제 도 운용으로 외국인력 도입 및 관리의 효율성을 도모해야 한다.

일곱째 국내 정책조정 체계나 사후관리 체계로 서 정부의 역할을 강화할 필요가 있다. 외국인어 선원에 대한 수요가 늘어나며 욕구가 다양해지므 로 외국인어선원 문제를 탄력적이고 통합적으로 그리고 책임 있게 관리하도록 할 수 있도록 고용 정책 및 관리의 중심은 국토해양부가 되어야 한 다. 그 방안의 하나로 외국인선원정책위원회 설 치를 검토할 필요가 있다.

여덟째 도입 후의 교육과 관리 그리고 출국에 이르기까지 사후관리가 보다 체계적이고 효율적 으로 이루어질 수 있도록 제도적 뒷받침이 되어 야 한다. 특히 무단이탈한 어선원을 불법으로 고 용하는 육상 사업자에 대한 단속 및 처벌을 강화 할 필요가 있다.

\section{참고 문헌}

김용복 외(2003). 연근해어업분야 산업연수생의 교육과정 고찰, 수산연구 $18,69 \sim 80$.

윤영삼 외(1997). 외국인어선원 활용정책의 과제 와 방향, 수산경영론집 28(2), 31 35.

차철표 외(2011). 연근해어선에 승무하는 외국인 어선원의 관리방안, 수산해양교육연구 23(3), 515 $\sim 525$.

- 논문접수일 : 2012년 02월 27일

- 심사완료일 : 1차 - 2012년 03월 10일

- 게재확정일 : 2012년 03월 23일 